\title{
PEMBELAJARAN BAHASA INDONESIA SECARA ONLINE PADA MASA PANDEMI COVID-19 DI SMA ISLAM TERPADU NUR HIDAYAH SUKOHARJO
}

\author{
Septirini Sekar Nusantari ${ }^{1}$, Sumarwati ${ }^{2}$, Atikah Anindyarini ${ }^{3}$ \\ Universitas Sebelas Maret \\ E-mail: skrnusantara@gmail.com ${ }^{1}$, sumarwati@staff.uns.ac.id ${ }^{2}$, \\ atikahanindyarini@staff.uns.ac.id ${ }^{3}$
}

\begin{abstract}
Abstrak: Penelitian ini bertujuan untuk mengetahui kendala pembelajaran Bahasa Indonesia secara online dan upaya penyelesaiannya di SMAIT Nur Hidayah Sukoharjo. Jenis penelitian ini merupakan kualitatif deskriptif. Teknik pengumpulan data dilakukan dengan analisis dokumen, observasi dan wawancara. Analisis data yang digunakan dalam penelitian ini yaitu pengumpulan data, reduksi data penyajian data dan kesimpulan. Hasil penelitian menunjukkan bahwa kendala yang dialami guru dan siswa selama pembelajaran daring yaitu pengawasan, aplikasi pembelajaran, fasilitas belajar dan jaringan internet.
\end{abstract}

Kata kunci: pembelajaran online, pembelajaran Bahasa Indonesia, kendala, upaya penyelesaian.

\section{ONLINE INDONESIAN TEACHING IN THE PANDEMIC TIME OF COVID-19 AT THE ISLAMIC HIGH SCHOOL TERPADU NUR HIDAYAH SUKOHARJO}

\begin{abstract}
This study aims to determine the obstacles to learning Indonesian online and efforts to solve them at SMAIT Nur Hidayah Sukoharjo. This type of research is descriptive qualitative. The data collection technique was carried out by document analysis, observation and interviews. Data analysis used in this research is data collection, data reduction, data presentation and conclusion. The results showed that the obstacles experienced by teachers and students during online learning were supervision, learning applications, learning facilities and internet networks.
\end{abstract}

Keywords: online learning, Indonesian language learning, constraints, resolution efforts.

\section{PENDAHULUAN}

Proses pembelajaran dimasa pandemi dilakukan dengan melaksanakan pembelajaran jarak jauh secara daring dari rumah masing-masing (Lestari \& Gunawan, 2020). Pemerintah melalui Menteri Pendidikan dan Kebudayaan mengeluarkan Surat Edaran Nomor 4 Tahun 2020 Tentang Pelaksanaan
Kebijakan Pendidikan Dalam Masa Darurat Penyebaran COVID, dalam Surat Edaran tersebut dijelaskan bahwa kegiatan belajar mengajar dilaksanakan di rumah melalui pembelajaran daring atau jarak jauh. Pembelajaran daring merupakan pembelajaran yang diselenggarakan tanpa adanya interaksi fisik dengan menggunakan bantuan platform 
digital berbasis internet (Putra \& Irwansyah, 2020). Pembelajaran daring memungkinkan adanya interaksi antara guru dan siswa dalam pembelajaran melalui teknologi internet. Pembelajaran daring atau pembelajaran jarak jauh bertujuan untuk memenuhi standar pendidikan dengan memanfaatkan teknologi informasi melalui perangkat komputer yang terhubung antara siswa dengan guru maupun sebaliknya sehingga melalui pemanfaatan teknologi tersebut kegiatan belajar mengajar tetap dapat dilaksanakan (Fitriani dan Pakpahan, 2020).

Virus corona yang menyebar hampir di seluruh dunia tidak terkecuali Indonesia berdampak di semua aspek kehidupan. World Health Organisation (WHO) menetapkan status pandemi pada 11 Maret 2020. Berbagai upaya dilakukan untuk mencegah bahkan memutus persebaran virus ini. Pemerintah Indonesia dalam hal ini menerapkan kebijakan seperti pembatasan sosial berskala besar (PSBB), penerapaan social distancing, karantina wilayah, dan kampanye untuk tetap di rumah saja. Langkah yang diambil pemerintah sebagai upaya memutus mata rantai Covid-19 berdampak diberbagai sektor, salah satunya pendidikan. Kebijakan tersebut memberikan dampak pada pendidikan di Indonesia khususnya pada pembelajaran di sekolah (Lestari \& Gunawan, 2020).
Peralihan dari pembelajaran secara tatap muka ke pembelajaran daring atau pembelajaran jarak jauh menjadi sesuatu yang baru bagi guru dan siswa (Rigianti, 2020). Sebagai sesuatu yang baru dalam dunia pendidikan pembelajaran daring memerlukan sinergi semua pihak yaitu guru, orang tua dan siswa untuk mengantisipasi kendala atau hambatan selama pembelajaran jarak jauh. Pada kenyataannya dari semua kegiatan dalam e-learning mengindikasikan bahwa tidak semua peserta didik akan berhasil dalam pembelajaran online. Hal ini disebabkan faktor lingkungan belajar dan karakteristik peserta didik itu sendiri (Nakayama dan Yamamoto, 2007). Pembelajaran online dimasa pandemi memberikan dampak dalam dunia pendidikan, baik dampak positif maupun negatif.pembelajaran secara daring di masa pandemi ini juga mengalami beberapa kendala yang dialami oleh guru, siswa, maupun orang tua siswa (Lestari \& Gunawa, 2020).

Kendala dialami oleh guru dan siswa selama melaksanakan pembelajaram online. Beberapa guru mengalami kendala dalam pelaksanaan pembelajaran yang berkaitan dengan aplikasi pembelajaran, jaringan internet, gawai, pengelolaan pembelajaran, penilaian dan pengawasan (Rigianti, 2020). Selain menimbulkan kendala bagi guru, pembelajaran daring dimasa pandemi juga menimbulkan 
kecemasan bagi siswa. Salah satu kendala yang muncul ialah kecemasan. Kecemasan tersebut muncul karena kurangnya pemahaman materi, keterbatasan waktu mengerjakan tugas, keterbatasan akses internet, munculnya kendala teknis dan kekhawatiran menghadapi materi (Oktrawirawan, 2020).

Berdasarkan uraian diatas, kendala yang telah disebutkan menjadi hal penting untuk dikaji guna memaksimalkan penyelengaraan pembelajaran Bahasa Indonesia secara daring atau online. Sehingga penelitian ini dibuat untuk mengetahui kendala yang terjadi selama pembelajaran Bahasa Indonesia secara online di SMAIT Nur Hidayah dan upaya penyelesaiannya.

\section{METODE PENELITIAN}

Penelitian ini menggunakan penelitian kualitatif dengan pendekatan studi kasus. Penelitian kualitatif mendeskripsikan dalam bentuk kata-kata dan bahasa menganai hal-hal yang dialami oleh subjek peneliti, seperti perilaku, tindakan, persepsi (Moeleong, 2010). Metode deskriptif dilakukan untuk menggambarkan keadaan yang terjadi selama kegiatan penelitian. Penelitian dilakukan di SMAIT Nur Hidayah Sukoharjo yang beralamat di Jalan Pandawa nomor 10, Dusun III, Pucangan, Kecamatan Kartasura,
Kabupaten Sukoharjo 57168. Subjek penelitian adalah siswa kelas X IPS 1 yang berjumlah 30 siswa dan guru pengampu mata pelajaran Bahasa Indonesia.

Teknik pengambilan data dalam penelitian ini dilakukan melalui tiga cara, yaitu analisis dokumen, observasi, dan wawancara. Sumber data dalam penelitian ini dari dokumen dan informan. Dalam penelitian ini menggunakan data berupa dokumen, yaitu RPP, silabus, dan hasil wawancara. Informan dalam penelitian ini ialah guru mata pelajaran Bahasa Indonesia dan beberapa siswa kelas X IPS 1 SMAIT Nur Hidayah Sukoharjo.

Data dalam penelitian kualitatif bersifat valid, reliabel, dan objektif. Penelitian data dikatakan valid jika tidak terdapat perbedaan antara yang dilaporkan oleh peneliti dengan adata yang ada di lapangan (Dwipa dkk, 2020). Teknik pengambilan sample dalam penelitian ini menggunakan teknik purposive sampling yaitu teknik pengambilan sampel karena pertimbangan tertentu. Dalam penelitian ini subjek yang dipilih dinggap mengetahui permasalahan yang diangkat peneliti dan dapat memberikan informasi yang diperlukan peneliti. Peneliti menggunakan teknik triangulasi sumber data dan triangulasi metode dalam penelitian ini.

HASIL DAN PEMBAHASAN 
Pembelajaran Bahasa Indonesia secara online di SMAIT Nur Hidayah Sukoharjo memanfaatkan teknologi internet dan media pembelajaran yang beragam disesuaikan dengan keperluan pembelajaran. Pembelajaran daring dilakukan menggunakan berbagai macam media (Oktawirawan, 2020). Sekolah menetapkan schoology sebagai media yang tidak hanya digunakan dalam mata pelajaran Bahasa Indonesia, namun seluruh mata pelajaraan yang ada. Selain memanfaatkan schoology, pembelajaran Bahasa Indonesia secara online juga memanfaatkan media lain. Schoology ialah salah satu learning management system (LMS) berbentuk web untuk mengelola pembelajaran yang memiliki tampilan seperti facebook dan dapat diakses tanpa biaya oleh siswa dan guru (Putri dkk, 2014).

Guru memanfaatkan blog, YouTube, dan Whatsapp untuk keperluan sumber belajar, serta Whatsapp untuk berinteraksi dengan siswa. Whatsapp dianggap lebih mudah digunakan sebagai media pembelajaran online karena aplikasi ini sudah menjadi media komuikasi sehari-hari (Zhafira et al., 2020).

\section{Pelaksanaan Pembelajaran Bahasa Indonesia secara online}

Pelakasanaan pembelajaran Bahasa Indonesia secara online tidak mengacu pada RPP yang ada karena pembelajaran dilaksanakan dalam waktu yang relatif singkat. Guru dan siswa dituntut untuk langsung melaksanakan pembelajaran secara online tanpa adanya persiapan terlebih dahulu. Setiap jenjang pendidikan dituntut untuk segera melek teknologi, meningkatkan kreatifitas, dan inovasi (Zaharah et al., 2020).

Kegiatan pembelajaran Bahasa Indonesia secara online yang dilaksanakan melalui schoology dimulai guru membuka kelas dengan salam dan dilanjutkan presensi. Materi disampaikan dengan mengunggah tautan sumber belajar di laman schoology. Tautan tersebut memuat materi belajar dari media sosial lain seperti blog ataupun YouTube. Guru juga memberikan tugas dengan memanfaatkan penggunaan media sosial seperti instagram. Strategi pembelajaran yang berbeda, seperti kuis dan pemberian hadiah juga dilakukan guru supaya kegiatan pembelajaran Bahasa Indonesia secara online tetap menarik minat siswa. Pemanfaatan sumber belajar dan strategi pembelajaran yang berbeda memiliki tujuan untuk membuat kegiatan belajar mengajar dalam kelas lebih beragam. Pembelajaran Bahasa Indonesia secara online diakhiri dengan pemberian umpan balik dari guru untuk siswa. Umpan balik diberikan dalam bentuk voice note berisi kesimpulan kegiatan belajar, penugasan dan pemberian rencana belajar selanjutnya yang dibagikan digrup WhatssApp kelas. Dalam kegiatan pembelajaran secara online, guru juga memanfaatkan media WhatssApp untuk terhubung dengan siswa dan orangtua. Guru dan 
orangtua perlu menjalin interaksi untuk memantau kegiatan belajar siswa selama pembelajaran online (Dewi, 2020).

\section{Kendala pembelajaran Bahasa Indonesia secara online}

Peralihan pembelajaran dari yang semula tatap muka menjadi pembelajaran online memunculkan banyak hambatan karena hal ini terjadi mendadak tanpa ada persiapan terlebih dahulu (Rigianti, 2020). Pembelajaran Bahasa Indonesia secara online sebagai sesuatu yang baru memiliki kendala. Tidak semua guru dan siswa siap dalam menghadapi perubahan sistem pembelajaran di masa ini (Morgan, 2020). Kendala tidak hanya dialami oleh guru, tapi juga oleh siswa.

Kendala yang dialami guru selama pembelajaran online terkait pengawasan dan pemanfaatan aplikasi pembelajaran. Guru mengalami kesulitan untuk memantau dan mengawasi siswa selama pembejaran secara online. Media schoology yang tidak memberikan fitur tatap muka membuat guru kesulitan memantau siswanya. Kendala lain yang dialami oleh guru ialah tuntutan untuk menyelenggarakan pembelajaran Bahasa Indonesia dengan teknologi informasi yang terhubung internet. Hal tersebut menjadi hal baru bagi guru karena pembelajaran Bahasa Indonesia sebelumnya yang diselenggarakan secara konvensional. Pembelajaran secara online menjadi tantangan besar bagi guru dan siswa karena penggunaan platform tertentu yang belum dibiasakan (Almanthari et al., 2020). Guru mengalami kesulitan untuk memilih, memanfaatkan, dan mengembangkan media pembelajaran secara online yang disesuaikan dengan kondisi siswaGuru yang tidak pernah menggunakan media online harus berusaha dan menyesuaikan kemampuannya dengan tuntutan saat ini (Oktawirawan, 2020).

Keberadaan media schoology tidak serta merta menyelesaikan permaslahaan terkait pemanfaaatan aplikasi pembelajaran secara online. Kondisi kelas yang berbeda-beda dan keadaan dimasa pandemi menuntut guru untuk menciptakan kegiatan pembelajaran yang menyenangkan dan bermakna. Kondisi pandemi dan tuntutan pembelajaran secara online membuat guru harus terampil dalam memanfaatkan berbagai cara guna menyelenggarakan kegiatan pembelajaran online yang efektif (Kauffman \& Vallade, 2020).

Selama pembelajaran Bahasa Indonesia secara online siswa juga mengalami kendala. Kendala yang dialami oleh siswa antara lain, teralihkan saat mengikuti pembelajaran secara online karena minimnya pantauan dari guru. Kemudahan untuk mengakses platform atau media sosial dan pemanfataannya dalam pembelajaran sering mengalihkan fokus atau konsentrasi siswa. Pembelajaran 
Bahasa Indonesia secara online yang diselenggarakan di rumah perlu pengawasan dari orangtua selaku pengganti peran guru, namun orangtua seringkali abai terhadap hal ini. Selain itu, beberapa orang tua siswa juga kurang terbiasa mendampingi siswa saat belajar di rumah (Purwanto, 2020).

Kendala dalam pembelajaran Bahasa Indonesia secara online yang juga dialami oleh siswa ialah terkait ketersediaan fasilitas belajar. Pembelajaran secara online menuntut ketersediaan fasilitas belajar yang mendukung kegiatan pembelajaran, seperti gadget atau komputer. Siswa terkendala fasilitas belajar seperti gadget dan komputer yang bukan milik pribadi atau harus berbagi dengan orangtua atau saudara yang juga mengikuti kegiatan pembelajaran online. Salah satu kendala yang dialami orangtua siswa ialah tidak semua orangtua siswa mempunyai gawai atau komputer yang tehubung ke internet (Lestari \&Gunawan, 2020). Fasilitas selain gadget atau komputer yang diperlukan siswa selama pembelajaran secara online ialah jaringan internet. Salah satu tantangan dalam pembelajaran daring adalah ketersediaan layanan internet (Sadikin \& Hamidah, 2020). Siswa sering mengalami kendala pada server dan jaringan internet yang lemah. Kedua hal tersebut mempengaruhi mengakibatkan siswa tidak dapat login ke kelas online dischoology dan mempengaruhi keikutsertaan siswa dalam pembelajaran secara online.

\section{Upaya mengatasi kendala pembelajaran Bahasa Indonesia secara online}

Upaya mengatasi kendala terkait kesulitan guru menjangkau siswa dilakukan dengan memaksimalkan keberadaan media WhatsApp. Guru dan siswa dapat menggunakan WhatsApp sebagai media diskusi pendidikan, akses sumber-sumber belajar dan pelaksanaan kegiatan pembelajaran dimana saja dan kapan saja (Wajdi ,dkk., 2020). Sementara kendala guru yang berkaitan dengan keterbatasan menggunakan media pembelajaran yang inovatif, sekolah berupaya memberikan ruang diskusi dan belajar bagi semua guru untuk bertukar ilmu dan pengetahuan mengenai semua hal dalam pembelajaran online. Sekolah membererikan ruang melalui grup WhatsApp untuk melakukan diskusi sesama guru.

Sementara upaya mengatasi kendala siswa yang terkait fokus dengan menutup akses ke akun lainnya saat mengikuti kegiatan pembelajaran. Guru juga berupaya untuk mengatasi kendala tersebut dengan mengatur waktu pelaksanaan pembelajaran.

Disarankan pembelajaran daring sebaiknya diselenggarakan dalam waktu yang tidak lama karena sulit mempertahankan konsentrasi atau 
fokusnya (Firman \& Rahman, 2020). Upaya untuk mengatasi kendala siswa terkait ketersediaan fasilitas belajar, gangguan pada server dan jaringan internet yang mempengaruhi keikutsertaan siswa dengan meminta izin ke guru. Siswa menjelaskan keadaan atau kendala yang terjadi pada guru sehingga guru memahami kondisi siswa. Guru juga memberikan toleransi pada siswa untuk terlambat mengikuti kegiatan pembelajaran. Orangtua selaku pihak yang menggantikan peran guru di rumah juga berupaya memenuhi kebutuhan fasilitas belajar siswa. Pembelajaran daring memerlukan dukungan perangkat yang dapat terhubung dengan internet seperti gawai, laptop, dan komputer yang dapat digunakan untuk mengakses informasi kapan saja dan dimana saja (Gikas \& Grant, 2013). Dalam hal ini siswa, orangtua dan guru harus bersinergi untuk dapat menyelesaikan kendala terkait fasilitas belajar siswa.

\section{SIMPULAN}

Pembelajaran secara daring atau online menjadi sesuatu yang baru dalam dunia pendidikan, baik bagi siswa ataupun guru. Pelaksanaannya memanfaatkan peragkat komputer dengan jaringan internet serta beragam media sosial dan aplikasi sebagai media dan sumber belajar. Dalam pelaksanaannya ditemukan kendala yang dialami oleh guru dan siswa. Guru mengalami kendala terkaita pengawasan dan pemanfaatan aplikasi pembelajaran. Guru memiliki keterbatasan untuk berinterkasi dengan siswa dan keterbatasan dalam menggunakan media pembelajaran yang memanfaatkan jaringan internet. Siswa juga mengalami kendala selama mengikuti kegiatan pembelajaran Bahasa Indonesia secara online, yaitu teralihkan fokus, keterbatasan fasilitas dan tidak dapat login ke kelas online. Guru memaksimalkan penggunaan media sosial WhatsApp untuk berinteraksi dengan siswa dan orangtua dan mengikuti diskusi dan bimbingan dari sekolah untuk mengambangakn kemampuan dalam mengeola kelas selama pembelajaran online. Sementara siswa berupaya menjaga fokus dengan menutup akses akun lain selama pembelajaran, meminta izin dan toleransi dari guru ketika terkendala fasilitas da jaringan internet yang buruk.

\section{REFERENSI}

Almanthari, A., Maulina, S., \& Bruce, S. (2020). Secondary School Mathematics Teachers' Views on E-learning Implementation Barriers during the COVID-19 Pandemic: The Case of Indonesia. Eurasia Journal of Mathematics, Science and Technology Education, 16(7), 1860.

Dwipa, D.P., Wardhani, N.E., \& Anindyarini A. (2020). Pelaksanaan Pembelajaran Menulis Cerita Fantasi: Studi 
Kasus Di Kelas Vii Smp Negeri

4 Surakarta. Basastra Jurnal Bahasa, Sastra, Dan Pengajarannya, 8 (1), 133-142.

Dewi, Wahyu .A.F. (2020). Dampak Covid-19 Terhadap Implementasi Pembelajaran Daring Di Sekolah Dasa. Edukatif : Jurnal Ilmu Pendidikan., 2(1), 55-61.

Firman \& Rahman, S. R., (2020) Pembelajaran Online di Tengah Pandemi Covid-19. Indonesian Journal of Educational Science (IJES), 02 (02), 81-89.

Gikas, J., \& Grant, M. M. (2013). Mobile computing devices in higher education: Student perspectives on learning with cellphones, smartphones \& social media. Internet and Higher Education.

Nakayama M., Yamamoto, H., \& S. R. (2007). The Impact of Learner Characterics on Learning Performance in Hybrid Courses among Japanese Students. Elektronic Journal ELearning, $5(3) .1$.

Oktriawan, D.H. (2020). Faktor Pemicu Kecemasan Siswa Dalam Pembelajaran Daring di Masa PandemiCovid-19. Jurnal Ilmiah Universitas Batanghari Jambi, 20 (2), 541-544.

Pakpahan R, \& Fitriani Y,. (2020). Analisa Pemanfaatan Teknologi Informasi Dalam Pembelajaran Jarak Jauh Di Tengah Pandemi Virus Corona Covid-19.Jurnal of Information System, Applied, Management, Accounting and Research, 4 (2), 30-36.
Purwanto, A., dkk. (2020). Studi Eksploratif Dampak Pandemi COVID-19 Terhadap Proses Pembelajaran Online di Sekolah Dasar. EduPsyCouns: Journal of Education, Psychology and Counseling, 2(1), 1-12.

Putra, R. S., \& Irwansyah, I. (2020). Media Komunikasi Digital, Efektif Namun Tidak Efisien, Studi Media Richness Theory dalam Pembelajaran Jarak Jauh Berbasis Teknologi di Masa Pandemi. Global Komunika: Jurnal Ilmu Sosial dan Ilmu Politik, 1(2), 1-13.

Putri, N., Jampel, N., \& Suartama, I. K. (2014). Pengembangan E-Learning Berbasis Schoology pada Mata Pelajaran IPA Kelas VIII di SMP Negeri 1 Seririt. Journal Edutech Universitas Pendidikan Ganesa, 2(1), 1-11.

Rigianti, H.A. (2020). Kendala Pembelajaran Daring Guru Sekolah Dasar di Kabupaten Banjarnegara. Elementary School, 7 (2), 297-302.

Wajdi, M. B. N., Ubaidillah, M. B., Rizal, H. S., Mulyani, S. dkk. (2020). Pendampingan Redesign Pembelajaran Masa Pandemi Covid-19 bagi Tenaga Pendidik di Lembaga Pendidikan berbasis Pesantren di Jawa Timur. Jurnal Pengabdian kepada Masyarakat 04 (01). 266-277.

Zaharah, Z., Kirilova, G. I., \& Windarti, A. (2020). Impact of Corona Virus Outbreak Towards Teaching and Learning Activities in Indonesia. 
SALAM: Jurnal Sosial dan Budaya Syar-i, 7(3), 269-282.

Mahasiswa Terhadap Perkuliahan Daring Sebagai Sarana Pembelajaran Selama masa Karantina Covid-19.
Zhafira, N. H., Ertika, Y., \& Chairiyaton. (2020). Persepsi Jurnal Bisnis Dan Kajian Strategi Manajemen, 4(1), 37-45. 